\title{
Increased number of circulating HTLV-1 infected cells in peripheral blood mononuclear cells of HTLV-1 uveitis patients: a quantitative polymerase chain reaction study
}

\author{
Ayako Ono, Manabu Mochizuki, Kazunari Yamaguchi, Norio Miyata, Toshiki Watanabe
}

Department of

Pathology, Institute of Medical Science,

University of Tokyo,

Tokyo, 4-6-1

Shirokanedai, Minato-

ku, Tokyo 108, Japan

A Ono

$\mathrm{T}$ Watanabe

Department of

Ophthalmology,

Kurume University

School of Medicine, 67

Asahimachi, Kurume,

Fukuoka 830

A Ono

M Mochizuki

Blood Transfusion

Service and

Department of

Internal Medicine,

Kumamoto University

School of Medicine, 1-

1-1 Honjo, Kumamoto,

Kumamoto 860

K Yamaguchi

Miyata Eye Hospital, 6-3 Kuraharamachi, Miyakonojou,

Miyazaki 885, Japan

N Miyata

Correspondence to:

Toshiki Watanabe, MD,

Department of Pathology,

Department of Pathology,
Institute of Medical Science

Institute of Medical Science,
University of Tokyo, 4-6-1,

Shireksinedai, Minato-ku,

Shirokanedai, Min
Tokyo 108, Japan.

Accepted for publication

4 October 1994

\begin{abstract}
Aims-This study aimed to characterise the status of viral infection in patients with HTLV-1 uveitis (HU) by quantifying the circulating HTLV-1 infected cells in the peripheral blood.

Methods-Genomic DNA samples of peripheral blood mononuclear cells (PBMC) were obtained from 25 patients with $H U, 14$ patients with tropical spastic paraparesis/HTLV-1 associated myelopathy (TSP/HAM), and 21 asymptomatic carriers of HTLV-1. Quantitative polymerase chain reaction (PCR) of the gag region of HTLV-1 provirus DNA was performed on these DNA samples. To confirm the PCR, genomic Southern blot hybridisation was performed to identify integrated HTLV-1 provirus. This procedure detected a few percent of HTLV-1 infected cells in the PBMC.

Results-Most of the HU patients had a significantly increased number of circulating HTLV-1 infected cells (mean (SD) $3 \cdot 84 \%(4 \cdot 45 \%)$ of the PBMC), whereas the percentage of infected cells in most asymptomatic carriers was less than $1 \%$ $(0 \cdot 54 \%(1 \cdot 11 \%))$. Most of the TSP/HAM patients also had a relatively high percentage $(11.63 \%(7 \cdot 67 \%))$. The differences among these three groups were highly significant bythe Mann-Whitney $U$ test.

Conclusion-The results suggested that the increase in the number of HTLV-1 infected cells is one base for the development of inflammatory HU lesions, as it is for TSP/HAM.

(Br F Ophthalmol 1995; 79: 270-276)
\end{abstract}

The human $\mathrm{T}$ cell leukaemia virus type $\mathrm{I}$ (HTLV-1) is causatively associated with a $T$ cell malignancy, adult $T$ cell leukaemia (ATL), ${ }^{1-7}$ and a chronic neurological disorder, tropical spastic paraparesis/HTLV-1 associated myelopathy (TSP/HAM). ${ }^{8-12}$ Recently, we reported a new disease entity associated with HTLV-1, HTLV-1 uveitis $(\mathrm{HU})$, based on our seroepidemiological, ophthalmic, and virological studies. ${ }^{13-18} \mathrm{HU}$ was tentatively defined as an idiopathic uveitis of otherwise asymptomatic HTLV-1 carriers. Clinically, HU is characterised by a sudden onset of mild iritis, moderate or severe vitreous opacities, and mild retinal vasculitis in one or both eyes. ${ }^{18}$ Cytological examination of the cells in the anterior chambers from affected eyes disclosed that the infiltrating cells are predominantly lymphocytes with CD3 surface marker (Ono et al, submitted for publication). HTLV-1 infected cells were demonstrated in all the samples examined ${ }^{13}$ by polymerase chain reaction (PCR). ${ }^{19}$ The intraocular inflammation responded well to topical and/or systemic corticosteroids and the visual prognosis of $\mathrm{HU}$ is good in most patients. ${ }^{16-18}$

TSP/HAM is a chronic inflammatory neurological disease of the CNS, mainly affecting the thoracic spinal cord resulting in spastic paraparesis. ${ }^{2021}$ Because of high levels of serum antibodies against HTLV-1 antigens and the presence of cytotoxic $T$ cells in peripheral blood mononuclear cells (PBMC), the host immune response has been implicated as one of the pathogenetic mechanisms. ${ }^{22-29}$ One of the characteristic findings is that the number of HTLV-1 infected cells in the PBMC of patients is increased polyclonally or, in some cases, oligoclonally. ${ }^{30-35}$ Although the mechanism of this increase is not yet understood, it is speculated that the increased number of HTLV-1 infected cells is also relevant to the development of the inflammatory CNS lesions characterised by the infiltration of T lymphocytes. ${ }^{2021}$

We tested whether patients with $\mathrm{HU}$, another inflammatory disease caused by HTLV-1, have an increased number of circulating HTLV-1 infected cells. We determined the number of HTLV-1 infected cells in fresh PBMC from these patients using semiquantitative PCR and conventional genomic Southern hybridisation. Our results indicated that the number of HTLV-1 infected cells in PBMCs is significantly increased in most HU patients compared with that of asymptomatic carriers, suggesting a common underlying HTLV-1 infection in $\mathrm{HU}$ and TSP/HAM patients. 


\section{Materials and methods}

PATIENTS WITH HU AND TSP/HAM

All the patients with HU or TSP/HAM and the asymptomatic carriers in this study were residents in the Kyushu area of Japan, where HTLV-1 is endemic. The number of patients with $\mathrm{HU}$ was 25 (five males and 20 females, mean age $44 \cdot 6$ ) and that of TSP/HAM patients 14 (five males and nine females, mean age 54.9). Twenty one asymptomatic carriers (15 males and six females, mean age 48.3) included 14 seropositive blood donors and seven volunteers. In all these groups, no family members were included except for one asymptomatic carrier who is a family member of a TSP/HAM patient. HU was clinically diagnosed according to our criteria. ${ }^{13-18}$ Briefly, idiopathic uveitis in the otherwise asymptomatic HTLV-1 carriers was diagnosed as HU. Peripheral blood samples of these patients contained no abnormal lymphocytes and the white blood cell count was within the normal range. TSP/HAM was clinically diagnosed using the criteria of Osame et $a l^{23}$ : gradual onset of progressive spastic paraparesis; symmetrical, predominantly upper motor neuron disorders with mild sensory and bladder disturbances; and high antibody titres to HTLV-1 antigens in the serum and cerebrospinal fluid (CSF).

ASSAY FOR ANTIBODIES TO HTLV-1

Serum antibodies to HTLV-1 antigens were tested using a commercially available particle agglutination kit (Fuji Rebio, Tokyo, Japan) and confirmed by an enzyme linked immunosorbent assay kit (Eizai Co Ltd, Tokyo, Japan).

GENOMIC DNA SAMPLES FROM PBMC

With their informed consent, peripheral blood samples were collected from 25 patients with HU, 14 patients with TSP/HAM, and 21 asymptomatic carriers. Fresh PBMC were isolated by density gradient centrifugation with Ficoll-Paque (Pharmacia LKB Biotechnology, Uppsala, Sweden). High molecular weight genomic DNA was extracted by the standard method using SDS/ProteinaseK and phenol chloroform extraction followed by ethanol precipitation. ${ }^{36}$ The concentration of the DNA was determined by spectrophotometry.

SEMIQUANTITATIVE PCR ANALYSIS

A primer pair for the HTLV-1 gag region was used to PCR amplify HTLV-1 provirus DNA (Table 1). As a positive control sample having

Table 1 Oligomers used for PCR analysis of HTLV-1 provirus

G1:5'-TTATGCAGACCATCCGGCTT-3' (1301-1320) G2:5' -TATCTAGCTGCTGGTGATGG-3' (1420-1401) G2:5'-TATCTAGCTGCTGGTGATGG-3' (1420-1401)

G1, G2 = primers for gag region of HTLV-1, G2 is the antisense primer. G3=internal oligomer probe. Numbers in the parenthesis is the nucleotide position of the original provirus clone, $\gamma$ ATK (ref 37). one copy of the HTLV-1 provirus per cell, we used the genomic DNA extracted from the PBMC of an ATL patient which contained more than $90 \%$ leukaemic cells. A fivefold dilution series of this ATL DNA was prepared by dilution with genomic DNA of the human $T$ cell line CEM, which is not infected with HTLV-1. The reaction volume of $50 \mu \mathrm{l}$ contained $0.5 \mu \mathrm{g}$ of template DNA. The reaction mixture contained $1 \mu \mathrm{mol} / 1$ of each primer, $200 \mu \mathrm{mol} / 1$ of each of the four nucleotide triphosphates, $1 \mathrm{mmol} / 1$ of $\mathrm{MgCl}_{2}$ and 1.25 units of Taq polymerase (Biotech International Ltd, Australia).

For semiquantitative PCR, template DNA samples for the patients and the control dilution series were amplified simultaneously, and one fifth of these products were resolved by $5 \%$ polyacrylamide gel electrophoresis followed by electrotransfer to a charged nylon membrane (Biodine B, Pall BioSupport Company, Glen Cove, NY, USA) using a semi-dry blotter. Thereafter, the membrane was denatured with $0.4 \mathrm{~N} \mathrm{NaOH}$ and neutralised with $0.5 \mathrm{M}$ TRIS $\mathrm{HCl}, \mathrm{pH} 8 \cdot 0$, and fixed by ultraviolet irradiation. Hybridisation with a ${ }^{32} \mathrm{P}$ labelled internal oligomer probe (G3) was done at $55^{\circ} \mathrm{C}$ in a hybridisation solution containing $4 \times$ SSC, $10 \times$ Denhardt solution, and $100 \mu \mathrm{g} / \mathrm{ml}$ of heat denatured $E$ coli DNA. After washing in $2 \times$ SSC and $0.1 \%$ SDS at $55^{\circ} \mathrm{C}$, the hybridised signal was quantified using a Bio-Image Analyser BA100 (Fuji Film, Tokyo, Japan). To estimate the copy number of the HTLV-1 provirus in the template DNA, a standard curve on a semilog scale was constructed from the measured radioactivity in the control dilution series. The samples were assayed by 30 cycles of amplification. When the samples contained more than a few per cent of the infected cells, 25 cycles of amplification were performed for confirmation. The percentage of the infected cells was calculated from the standard curve based on the following assumptions: that the positive control DNA of ATL cells contains one copy of HTLV-1 provirus per cell which was verified by genomic Southern blotting with an HTLV-1 DNA probe; that $0.5 \mu \mathrm{g}$ of DNA corresponds to $0.75 \times 10^{5}$ cells; and that HTLV-1 infected cells in vivo have one copy of its provirus per cell.

SOUTHERN HYBRIDISATION OF THE INTEGRATED HTLV-1 PROVIRUS

To test the sensitivity of the blot, a twofold dilution series of the positive control DNA was prepared using ATL DNA and DNA of the HTLV-1 negative human $T$ cell line, Jurkat. Ten $\mu \mathrm{g}$ of genomic DNA of this dilution series and the DNA samples were digested with PstI, which has six recognition sites within the HTLV-1 provirus genome. Following electrophoresis on a $1 \%$ agarose gel, the DNA was transferred to a nylon membrane by capillary blotting with $0.4 \mathrm{~N} \mathrm{NaOH}$. The membrane was neutralised with $0.5 \mathrm{M}$ TRIS $\mathrm{HCl}, \mathrm{pH} 8.0$, fixed by ultraviolet irradiation and hybridised at $65^{\circ} \mathrm{C}$ in a hybridisation solution containing 
A

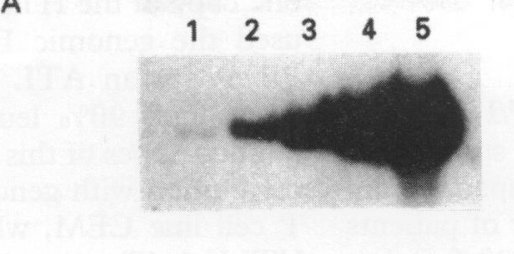

B

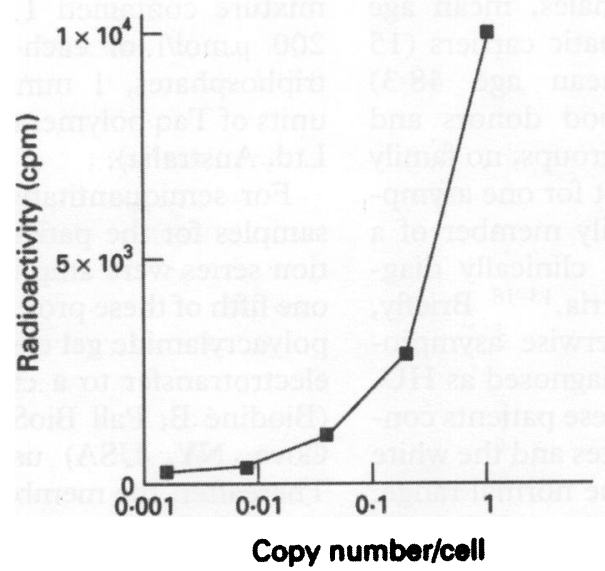

C
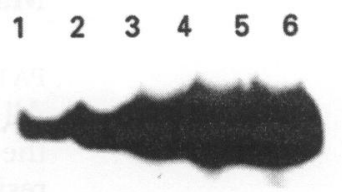

D

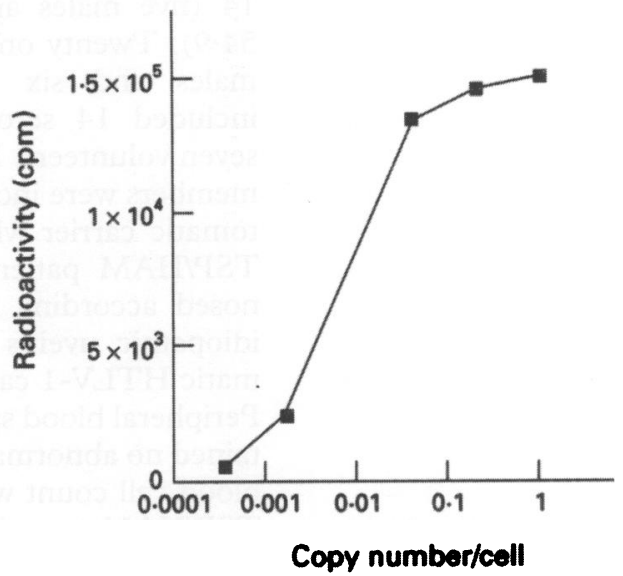

Figure 1 Semiquantitative amplification of HTLV-1 provirus DNA by gag region PCR. A fivefold dilution series of positive control DNA was amplified by PCR and the products were hybridised with an internal oligomer probe. The radioactivity of each product was measured and plotted on a semi-log scale graph. $(A)$ and $(C)$, autoradiogram of blotted $P C R$ products (A: 25 cycles, $C: 30$ cycles), (B) and (D) plot of radioactivity of each product (B: 25 cycles, D: 30 cycles).

$4 \times$ SSC, $5 \times$ Denhardt solution, and $100 \mu \mathrm{g} / \mathrm{ml}$ of heat denatured salmon sperm DNA and a probe for total HTLV-1 provirus DNA or an env gene specific probe that was labelled with ${ }^{32} \mathrm{P}$ using the Megaprime kit (Amersham International plc, Bucks). After washing at $65^{\circ} \mathrm{C}$ in $0.5 \times \mathrm{SSC}$ and $0.1 \% \mathrm{SDS}$, the membrane was exposed to X-Omat AR film (Eastman Kodak, Rochester, NY) with a Lightening Plus intensifying screen (E I du Pont de Nemours \& Company, Wilmington, DE, USA) at $-70^{\circ} \mathrm{C}$ for periods ranging from overnight to 7 days.

\section{Results}

\section{SEMIQUANTITATIVE PCR OF THE HTLV-1} PROVIRUS DNA

The amount of PCR products in the control dilution series was almost linearly related to the copy number of HTLV-1 provirus DNA in the template over the range of a $5^{-2}$ to $5^{-0}$ dilution, by 25 amplification cycles, and of a

A

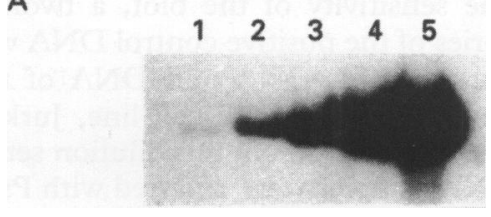

$5^{-3}$ to $5^{-1}$ dilution by 30 cycles (Fig 1 ). Therefore, 30 cycles were considered optional for quantifying the products from most of the HU patients and asymptomatic carriers, whereas 25 cycles was used to quantify those in some of the TSP/HAM patients whose PBMC contained more than $10 \%$ of infected cells.

Because the efficiency of amplification varied to some extent in each PCR, the control dilution series DNA and the patient samples were amplified simultaneously and analysed on the same gel and membrane. Some of these results are shown in Figure 2, and they demonstrate the increased viral DNA load in HU patients (Fig 2, lanes 6-10) compared with that of asymptomatic carriers (Fig 2, lanes 11-13).

The calculated percentage of HTLV-1 infected cells in the PBMC in the three groups of HTLV-1 carriers was plotted on a semilog scale (Fig 3). Among the $25 \mathrm{HU}$ patients studied, $18(72.0 \%)$ had more than $1 \%$ of infected cells. The percentage of HTLV-1 infected cells in the PBMC in $\mathrm{HU}$ patients ranged from $0.1 \%$ to $17 \%$, with the mean (SD) of $3 \cdot 84 \%$ $(4 \cdot 45 \%)$. Among the asymptomatic carriers, 17 of $21(81.0 \%)$ contained less than $1 \%$ of HTLV-1 infected cells in the PBMC, with 11 out of $21(52.4 \%)$ having about $0.1 \%$ or less (mean (SD) $0.54 \%(1 \cdot 11 \%)$ ). It is notable that four of the 21 samples $(19 \%)$ contained over $1 \%$ of infected cells, which contributed to the wide distribution and relatively high mean percentage. The percentage of infected cells in one asymptomatic family member of a TSP/HAM patient was $0 \cdot 25 \%$. Of the 14 TSP/HAM patients, more than $5 \%$ of the infected PBMC were in $12(85 \cdot 7 \%)$ of them, the highest being $25 \%$ (mean (SD) $11.63 \%$ $(7 \cdot 67 \%)$ ). The PBMC of the remaining two patients $(14.3 \%)$ contained about $1 \%$ or less of
Figure 2 Quantitative PCR of HTLV-1 provirus DNA in the samples. An autoradiogram of the membrane hybridisation of the PCR products (30 cycles) with internal oligomer probe, $G 3$, is presented. The membrane was exposed to X-Omat AR film for 1 hour. (A) Fivefold dilution series of the positive control $\left(5^{0}\right.$ to $5^{-4}$ from lanes 1 to 5 ), (B) samples from HU patients (lanes 6 to 10); (C) samples from asymptomatic carriers (lanes 11 to 13). 


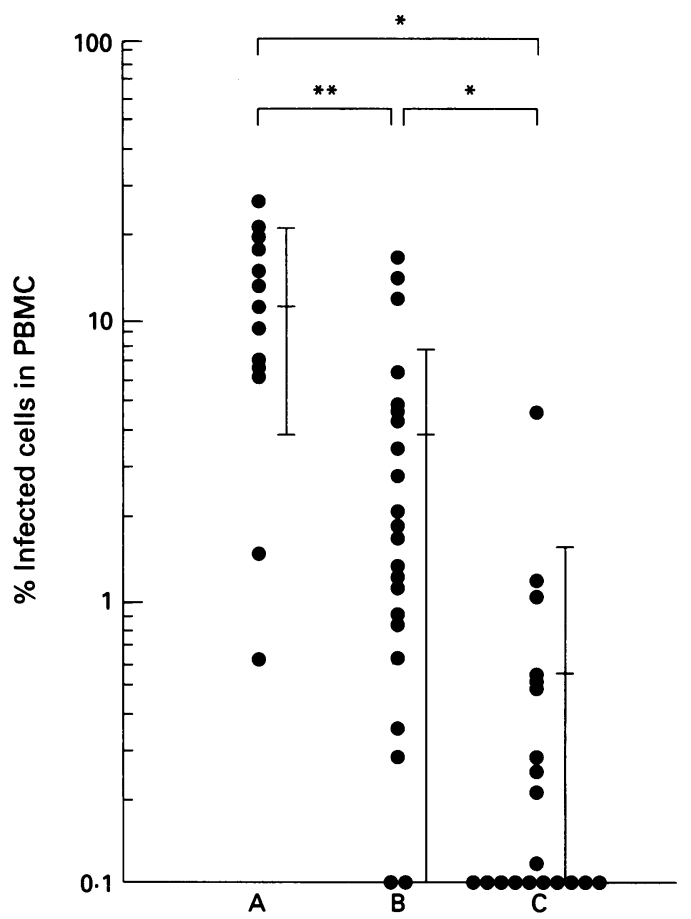

Figure 3 Increased population of HTLV-1 infected cells in the PBMC of patients with $H U$ and TSP/HAM. The calculated percentage of $H T L V-1$ infected cells in each sample was plotted on a semi-log scale. The means and the standard deviations are indicated for each group. (A) TSP/HAM patients ( $n=14$, mean (SD) 11.63 (7.67)), (B) HU patients ( $n=25$, mean (SD) 3.84 (4.45)), (C) asymptomatic carriers $(n=21$, mean (SD) $0.54(1 \cdot 11))$. ${ }^{\star} p=0.0001,{ }^{\star} p=0.0008$ by Mann-Whitney U test.

the infected cells, which is compatible with previous reports where $80-85 \%$ of the patients showed hybridisation signals on Southern blots with an HTLV-1 probe.

Although the range was widely distributed in each group, the increases of the HTLV-1 infected cells in the PBMC of the patients with HU and TSP/HAM were both highly significant when compared with asymptomatic carriers $(p=0.0001$ for both by Mann-Whitney $\mathrm{U}$ test). The difference in the ratio of the infected cells between the patients with HU and TSP/HAM was also significant $(p=0.0008$ by Mann-Whitney $U$ test).

\section{GENOMIC SOUTHERN HYBRIDISATION}

To confirm the increase of HTLV-1 infected cells by a different method, we studied the above samples by genomic Southern hybridisation of the integrated HTLV-1 provirus. PstI cleaves the HTLV-1 provirus at six sites, producing three large fragments from the internal region and two from the viral cellular junctions (Fig 4A), if the provirus is intact. The representative HTLV-1 probe in this study covers the whole viral genome from the 5'-LTR to the 3'-LTR, so that all the fragments produced by PstI digestion, internal ones and, when monoclonal population was present, those with LTR and flanking cellular sequence, were detectable, unless they were too small to run on the agarose gel. To assess the sensitivity of the Southern blots, we included positive controls consisting of a twofold dilution series of ATL DNA in the assay. After an overnight exposure to X-Omat AR film (Kodak), the hybridised bands of the internal restriction fragments were visible on the lanes of these control samples until $2^{-5}$ dilution, indicating that the assay can detect a low percentage of the infected cells among the HTLV-1 negative cells (Fig 4B, lanes 1-7). On the same film, those hybridised bands were visible in three samples (Fig 4B, lanes 9, 10, 12). The intensity of these bands were comparable with those of a $2^{-5}$ dilution of ATL DNA, indicating that these patients have about $3 \%$ or more HTLV-1 infected PBMC. No junction fragments containing the LTR sequence and flanking cellular DNA were detected in HU patients, suggesting that no clonal proliferation had occurred.

Although the sensitivity of our Southern blot analysis was close to the limit of the method itself, we further tried to increase the sensitivity of our assay by using a region specific probe. Figure 4C shows one of the results with an env region specific probe that detects a $2.4 \mathrm{kbp}$ internal PstI fragment of the integrated HTLV-1 provirus DNA.

As for the samples in Figure 4B, semiquantitative PCR showed that about $1 \cdot 6,3 \cdot 7$, and $6.2 \%$ of the PBMC were infected in the HU patients in lanes 9,10 , and 12 , respectively. The samples in lanes 8,11 , and 13 were also from HU patients. PCR had shown that they contained $0.066,0.58$, and $0.29 \%$ infected cells, respectively. The sample in lane 14 was from a seropositive patient with a different ocular disease whose PBMC contained $0.016 \%$ infected cells. In Figure 4C, a band of env region was detectable to $2^{-6}$ dilution, which corresponds to $1.56 \%$ of infected population. Based on the semiquantitative PCR results, the PBMC of $\mathrm{HU}$ patients in lanes 4 to 8 contained $3 \cdot 7,4 \cdot 6,6 \cdot 2,14 \cdot 0$, and $4 \cdot 1 \%$ infected cells, respectively. Thus, these methods of semiquantifying the infected cells, PCR and Southern blot analysis, were comparable. However, Southern blots cannot be applied to samples that are infected at a low percentage.

\section{Discussion}

In addition to ATL and TSP/HAM, the disorders which have been associated with HTLV-1 include alveolitis, Sjögren syndrome, polymyositis, dermatitis, and arthropathy. ${ }^{38-45}$ Although these disorders, except for ATL and TSP/HAM, did not have strong epidemiological or clinical data to support their distinction as a clinical entity, a wide spectrum of HTLV1 pathogenicity has been suggested. Recently, we reported a uveitis associated with HTLV-1 (HU) which has an array of these features and could be considered a third disease caused by HTLV-1 infection. ${ }^{13-18}$

We showed here, by semiquantitative PCR, that the number of circulating HTLV-1 infected PBMCs was significantly increased to a few percentage points or more in most $\mathrm{HU}$ patients, and to about $10 \%$ or more in those with TSP/HAM, whereas it was less than $1 \%$ in most asymptomatic carriers. We confirmed these results by genomic Southern hybridisa- 
A

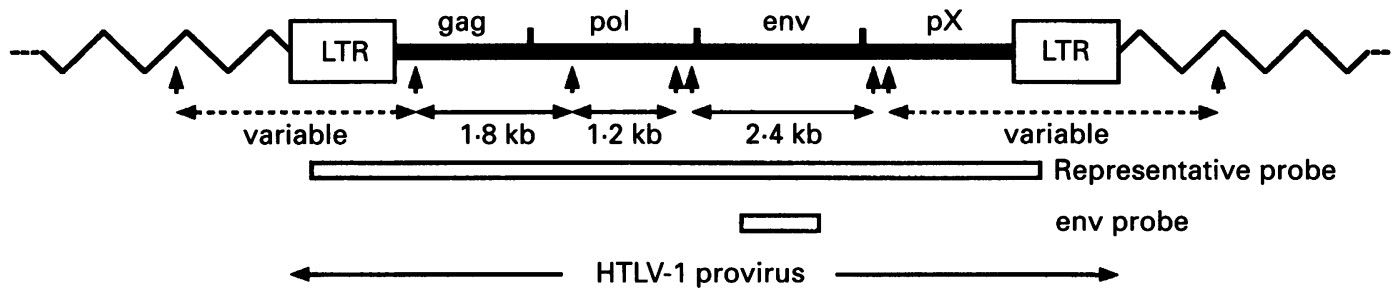

B

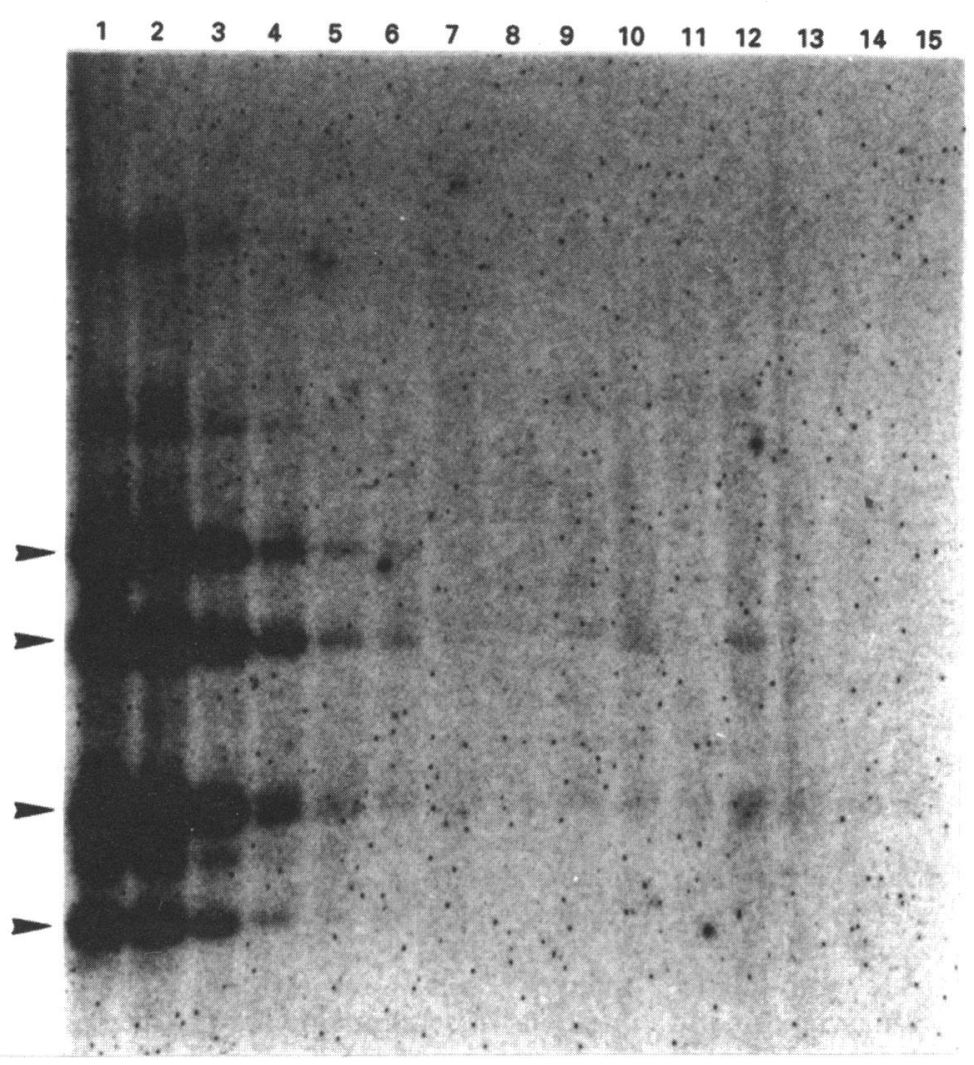

tion of the integrated HTLV-1 provirus and dilution studies.

Our results demonstrated that the increase in the HTLV-1 infected cells is a common feature of both HU and TSP/HAM. The percentage of the infected cells, however, showed a rather wide distribution, overlapping that of asymptomatic carriers. Thus the increase itself was not considered to be pathognomonic for these inflammatory disorders. It was already reported that TSP/HAM patients have an increased number of circulating HTLV-1 infected cells in the PBMC. ${ }^{30-35}$ Yoshida et al first reported that detection of the PstI digested internal fragment of the HTLV-1 provirus by conventional Southern blotting indicated the increased replication of the virus in these patients. ${ }^{3031}$ Using the same method, they later demonstrated an increase in the number of HTLV-1 infected cells in 84,52 , and $20 \%$ of the TSP/HAM patients, in seropositive family members of the patients with TSP/HAM and asymptomatic carriers, respectively. ${ }^{35}$ They also found that $19 \%$ of the TSP/HAM patients and $16 \%$ of their seroposi-
C

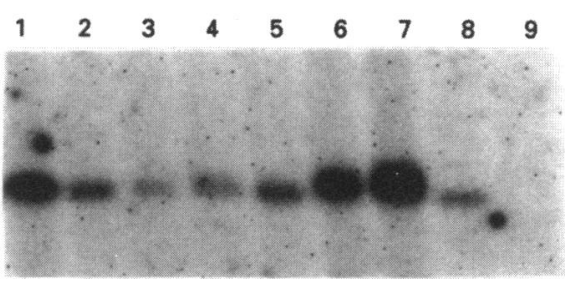

Figure 4 Analysis of the population of HTLV-1 infected cells by Southern blots of the integrated HTLV-1 provirus. (A) Schematic presentation of the integrated HTLV-1 provirus DNA; the PstI site is indicated by an arrow. (B) Autoradiogram of a representative result. Arrowheads indicate the position of the internal PstI fragments of the HTLV-1 provirus. Lanes 1-7, twofold dilution series of $A T L D N A\left(2^{0}\right.$ to $\left.2^{-6}\right)$; lanes 8-13, samples from $H U$ patients; lane 14, sample from a seropositive patient with a different ocular disease; lane 15, furkat cell DNA. (C) Autoradiogram of a result with an env gene specific probe and 7 day exposure of the film. Lanes $1-3$, samples of $2^{-4}$ to $2^{-6}$ dilution of $A T L D N A$; lanes 4-8, samples from $H U$ patients; lane 9, furkat cell DNA.

tive family members showed oligoclonal or monoclonal expansion of the HTLV-1 infected cells, whereas no clonal proliferation was detected in asymptomatic carriers in the general population. Our Southern blots of HU patients with representative and region specific probes also detected internal fragments of PstI digested HTLV-1 proviral DNA, indicating that more than a few percent of PBMC are infected with HTLV-1. About one third of the HU samples were positive in this assay, which roughly corresponds with the number that were shown by PCR to contain more than $3 \%$ infected cells. However, junction fragments containing LTR sequence have not yet been detected (Fig 4B), which suggests that no clonal proliferation at a detectable level has taken place in HU patients. To address this point by a more sensitive method, we are now investigating the clonal population in the PBMC of HU patients using inverse PCR to amplify LTR and flanking cellular DNA. ${ }^{46}$ Our preliminary results suggest that oligoclonal expansion of the HTLV-1 infected cells has taken place in the PBMC of HU patients, but not in that of asymptomatic carriers (Takemoto et al, unpublished observation).

The results of our quantitative PCR of cells from TSP/HAM patients were comparable with the $3-15 \%$ found by Gessain et al by Southern blotting with dilution series. ${ }^{33}$ Our results were also similar to those of Kira et al, who performed semiquantitative PCR. ${ }^{34}$ Our 
results showed that patients with $\mathrm{HU}$ or TSP/HAM have 10-100 times more HTLV-1 infected cells than asymptomatic carriers. This increase could be explained either by the proliferation of the HTLV-1 infected cells or by the efficient replication of the virus in these individuals. The presence of a clonal population in the PBMC of TSP/HAM patients ${ }^{35}$ and also in that of HU patients (Takemoto et al, unpublished observation) suggests that it resulted from the proliferation of the HTLV-1 infected cells in vivo. This expansion seems to precede the development of TSP/HAM, because $50 \%$ of the asymptomatic family members of TSP/HAM also have the increase. ${ }^{35}$

One of the non-structural, regulatory proteins of HTLV-1, Tax1, transactivates the expression of both viral and host cellular genes. Among the genes that are transactivated are those of cytokines such as IL-2, IL-3, IL-4, GM-CSF, and TGF $\beta .^{47-51}$ Thus, it is conceivable that the increased number of HTLV-1 infected $\mathrm{T}$ cells may lead to disturbances in the host immune response through the presentation of viral antigens and/or aberrant functions induced by $\mathrm{Tax} 1$, which results in inflammatory disorders such as HU and TSP/HAM. Whether such pathogenetic processes are involved in these two disorders can be tested by characterising the immunological abnormalities and the status of the viral infection in HU patients and their family members.

In conclusion, we demonstrated that patients with $\mathrm{HU}$ and TSP/HAM have much more HTLV-1 infected $T$ cells compared with asymptomatic carriers. These common features of viral infection might be the basis for the development of inflammatory disorders in HTLV-1 carriers.

This study was supported in part by a grant in aid for cancer research to Toshiki Watanabe, Manabu Mochizuki, and Kazunari Yamaguchi, a grant in aid for scientific research to Manabu Mochizuki, and a grant in aid for encouragement of young scientists to Ayako Ono, all from the Japanese Ministry of Education, Science and Culture, and also a grant from The Mitsubishi Foundation to Manabu Mochizuki.

1 Uchiyama T, Yodoi J, Sagawa K, Takatsuki K, Uchino H. Adult $\mathrm{T}$ cell leukemia: clinical and hematological features of 16 cases. Blood 1977; 50: 481-91.

2 Poiesz BJ, Ruscetti FW, Gazdar AF, Bunn PA, Gallo RC. Detection and isolation of type $C$ retrovirus particles from fresh and cultured lymphocytes of a patient with fresh and cultured lymphocytes of a patient with cutaneous T-cell

3 Yoshida M, Miyoshi I, Hinuma Y. Isolation and characterization of retrovirus from cell lines of human adult $\mathrm{T}$ cell leukemia and its implication in the disease. Proc Natl Acad Sci USA 1982; 79: 2031-5.

$4 \mathrm{Kim} \mathrm{JH}$, Durack DT. Manifestations of human Tlymphotropic virus type 1 infection. $A m$ F Med 1988; 84: 919-28.

5 Smith MR, Greene WC. Molecular biology of the type I human T-cell leukemia virus (HTLV-1) and adult T-cell leukemia. $f$ Clin Invest 1991; 87: 761-6.

6 Takatsuki K, Yamaguchi K, Watanabe T, Mochizuki M, Kiyokawa T, Mori $S$, et al. Adult $T$-cell leukemia and HTLV-1 related diseases. In: Takatsuki K, Hinuma Y, Yoshida M, eds. Gann monograph on cancer research No 39. Advances in adult T-cell leukemia and

7 Yamaguchi $K$. Human T-lymphotropic virus type 1 in Japan. Lancet 1994; 343: 213-6.

8 Gessain A, Barin F, Vernant JC, Gout O, Maurs L, Calender $\mathrm{A}$, et al. Antibodies to human $\mathrm{T}$ lymphotropic virus type-1 in patients with tropical spastic paraparesis. Lancet 1985; ii: 407-10.

9 Osame M, Usuku K, Izumo S, Ijicki N, Amitani H, Igata A, et al. HTLV-1-associated myelopathy, a new clinical entity. Lancet 1986; 1: 1031-2.

10 Vernant JC, Maurs L, Gessain A, Barin F, Gout O, Delaporte JM, et al. Endemic tropical spastic paraparesis associated with human T-lymphotropic virus type 1: a clinical and seroepidemiological study of 25 cases. Ann Neurol 1987; 21: 123-9.

11 Brew BJ, Price RW. Another retroviral disease of the nervous system: chronic progressive myelopathy due to HTLV-1. N Engl f Med 1988; 318: 1195-6.

12 Osame M, Kumamoto I, Izumo S, Armurak K, Nakagawa M, Maruyama I, et al. HTLV-1-associated myelopathy (HAM): epidemiology, clinical features, and pathomechanism. In: Takatsuki K, Hinuma Y, Yoshida M, eds. Gann monograph on cancer research No 39. Advances in Gann monograph on cancer research No 39 . Advances in CRC Press, 1992: 57-68.

13 Mochizuki M, Watanabe T, Yamaguchi K, Takatsuki K, Yoshimura K, Shirao M, et al. HTLV-1 uveitis: a distinct clinical entity caused by HTLV-1. Fpn f Cancer Res 1992; 83: 236-9.

14 Mochizuki $M$, Yamaguchi $K$, Takatsuki $K$, Watanabe $T$, Mori S, Tajima K. HTLV-1 and uveitis. Lancet 1992; 339: 1110

15 Mochizuki $M$, Watanabe $T$, Yamaguchi $K$, Tajima $K$, Yoshimura K, Nakashima S, et al. An uveitis associated with human T-lymphotropic virus type-1 (HTLV-1): with human T-lymphotropic virus type-1 (HTLV-1): Infect Dis 1992; 166: 943-4.

16 Mochizuki M, Watanabe T, Yamaguchi K, Yoshimura K, Nakashima S, Shirao M, et al. Uveitis associated with human T-cell lymphotropic virus type-1. Am $\mathcal{F}$ Ophthalmol 1992; 114: 123-9.

17 Mochizuki $M$, Tajima $K$, Watanabe $T$, Yamaguchi $K$. Human $\mathrm{T}$ lymphotropic virus type 1 uveitis. $B r \dot{f}$ Ophthalmol 1994; 78: 149-54.

18 Yoshimura $\mathrm{K}$, Mochizuki M, Araki S, Miyata N, Yamaguchi $\mathrm{K}$, Tajima $\mathrm{M}$, et al. Clinical and immunologic features of human T-cell lymphotropic virus type I uveitis. Am f Ophthalmol 1993; 116: 156-63.

19 Saiki RK, Scharf S, Faloona F, Mullis KB, Horn GT, Erlich $\mathrm{HA}$, et al. Enzymatic amplification of $\beta$-globin genomic sequences and restriction site analysis for diagnosis of sickle cell anemia. Science 1985; 230: 1350-4

20 Akizuki S, Nakazato O, Higuchi Y, Tanabe K, Setoguchi $M$, Yoshida $S$, et al. Necropsy findings in HTLV-1-associated myelopathy. Lancet 1987; i: 156-7.

21 Iwasaki Y, Ohara Y, Kobayashi I, Akizuki S. Infiltration of helper/inducer $T$ lymphocytes heralds central nervous system damage in human T-cell leukemia virus infection. $A m$ f Pathol 1992; 140: 1003-7.

22 Gessain A, Caudie C, Gout O, Vernant J-C, Maurs L, Giordano $\mathrm{C}$, et al. Intrathecal synthesis of antibodies to human $T$ lymphotropic virus type 1 and the presence of IgG oligoclonal bands in the cerebrospinal fluid of patients with endemic tropical spastic paraparesis. F Infect patients with endemic tropic

23 Osame M, Matsumoto M, Usuku K, Izumo S, Ijichi N, Amitani $\mathrm{H}$, et al. Chronic progressive myelopathy associated with elevated antibodies to human T-lymphotropic virus type 1 and adult T-cell leukemia like cells. Ann Neurol 1987; 21: 117-22.

24 Itoyama Y, Minato S, Kira J-I, Goto I, Sato H, Okochi K, et al. Altered subsets of peripheral blood lymphocytes in patients with HTLV-1 associated myelopathy (HAM). Neurology 1988; 38: 816-8.

25 Jacobson S, Gupta A, Mattson D, Mingioli E, McFarlin DE. Immunological studies in tropical spastic paraparesis. Ann Neurol 1989; 27: 149-56.

26 Minato S, Itoyama Y, Fujii N, Kira J, Goto I, Yamamoto N. Activated $\mathrm{T}$ cells in HTLV-1-associated myelopathy: autologous mixed lymphocyte reaction. Ann Neurol 1989; 26: 398-401

27 Ijichi S, Eiraku N, Osame M, Izumo S, Kubota R, Maruyama I, et al. Activated T lymphocytes in cerebrospinal fluid of patients with HTLV-1 associated myelopathy (HAM/TSP). I Neuroimmunol 1989; 25: 251-4.

28 Matsumoto $M$, Sugimoto $M$, Nakashima H, Imamura $F$ Kawano O, Uyama E, et al. Spontaneous T cell proliferation and release of soluble interleukin-2 receptors in patients with HTLV-1-associated myelopathy. Am $\mathcal{F}$ Trop patients with HTLV-1-associat

29 Nagasato K, Nakamura T, Ohishi K, Shibayama K, Motomura M, Ichinose $\mathrm{K}$, et al. Active production of antihuman T-lymphotropic virus type 1 (HTLV-1) IgM antibody in HTLV-1-associated myelopathy. $\mathcal{f}$ Neuroimmunol 1991; 32: 105-9.

30 Yoshida M, Osame M, Ususku K, Matsumoto M, Igata $A$. Viruses detected in HTLV-1 associated myelopathy and adult T-cell leukemia are identical in DNA blotting. Lancet 1987; i: 1085-6.

31 Yoshida M, Osame M, Kawai H, Toita M, Kuwasaki N, Nishida Y, et al. Increased replication of HTLV-1 in HTLV-1-associated myelopathy. Ann Neurol 1989; 26: HTLV-1.

32 Greenberg SJ, Jacobson S, Waldman TA, MacFarlin DE. Molecular analysis of HTLV-1 proviral integration and T cell receptor arrangement indicates that $T$ cells in tropical spastic paraparesis are polyclonal. $\mathcal{F}$ Infect Dis 1989; 159: $741-4$.

33 Gessain A, Saal F, Gout O, Daniel M-T, Flandrin G, deThe $G$, et al. High human $T$-cell lymphotropic virus type 1 proviral DNA load with polyclonal integration in peripheral blood mononuclear cells of French West Indian, Guianese and African patients with tropical spastic paraparesis. Blood 1990; 75: 428-33.

34 Kira J, Koyanagi Y, Yamada T, Itoyama Y, Goto I, Yamamoto N, et al. Increased HTLV-1 proviral DNA in HTLV-1-associated myelopathy: a quantitative 
polymerase chain reaction study. Ann Neurol 1991; 29: 194-201.

35 Furukawa Y, Fujisawa J, Osame M, Toita M, Sonoda S, Kubota $\mathbf{R}$, et al. Frequent clonal proliferation of human T-cell leukemia virus type 1 (HTLV-1)-infected T cells in HTLV-1-associated myelopathy (HAM-TSP). Blood 1992; 80: 1012-5.

36 Sanbrook J, Fritsch EF, Maniatis T. Molecular cloning, a labratory manual. 2nd ed. Cold Spring Harbor Laboratory Press, 1989.

37 Seiki M, Hattori S, Hirayama Y, Yoshida M. Human adul T-cell leukemia virus: complete nucleotide sequence of the provirus genome integrated in leukemia cell DNA the provirus genome integrated in leukemia

38 Sugimoto $M$, Nakashima $H$, Watanabe $S$, Uyama $E$, Tanaka $\mathrm{F}$, Ando $\mathrm{M}$, et al. T-lymphocyte alveolitis in HTLV-1-associated myelopathy. Lancet 1987; ii: 1220.

39 Sugimoto $M$, Nakashima $H$, Matsumoto $M$, Uyama $E$, Ando M, Araki S. Pulmonary involvement in patients with HTLV-1-associated myelopathy: increased soluble IL-2 receptors in bronchoalveolar lavage fluid. Am Rev Respir Dis 1988; 139: 1329-34.

40 Vernant JC, Buisson G, Magdeleine J, T-lymphocyte alveolitis, tropical spastic paraparesis, and Sjögren syndrome. Lancet 1988; i: 177 .

41 Wiley C, Nerenberg M, Cros D, Soto-Aguilar MC. HTLV1 polymyositis in a patient also infected with human mmunodeficiency virus. $N$ Engl f Med 1989; 320: 992-5.

42 Morgan OS, Rogers-Johnson P, Mora C, Char G. HTLVand polymyositis in Jamaica. Lancet 1989; ii: 1184-7.

43 Lagrenade L, Hanchard B, Fletcher V, Cranston B, Blattner W. Infective dermatitis of Jamaican children: a marker for HTLV-1 infection. Lancet 1990; 336: 1345-6.

44 Kitajima I, Yamamoto K, Sato K, Nakajima Y, Nakajima T Maruyama I, et al. Detection of human $\mathrm{T}$ cell lymphotropic virus type 1 proviral DNA and its gene expres- sion in synovial cells in chronic inflammatory arthropathy. 3 Clin Invest 1991; 88: 1315-22.

45 Kwakura Y, Tosu M, Yoshida E, Takiguchi M, Sato K, Kitajima I, et al. Induction of inflammatory arthropathy resembling rheumatoid arthritis in mice transgenic for HTLV-1. Science 1991; 253: 1026-8.

46 Takemoto S, Matsuoka M, Yamaguchi K, Takatsuki K. A novel diagnostic method of ATL: monoclonal integration of HTLV-1 provirus DNA detected by inverse PCR. Blood (in press).

47 Maruyama $M$, Shibuya $H$, Harada $H$, Hatakeyama $M$, Seiki M, Fujita $T$, et al. Evidence for aberrant activation of the interleukin-2 autocrine loop by HTLV-1-encoded of the interleukin-2 autocrine loop by HTLV-1-encoded $\mathrm{p} 40^{\mathrm{x}}$ and
$343-49$.

48 Miyatake S, Seiki M, DeWaal Malefijt R, Heike T, Fujisawa $\mathrm{J}$, Takebe $\mathrm{Y}$, et al. Activation of $\mathrm{T}$ cell-derived lymphokine genes in $T$ cells and fibroblasts: effects of human $T$ cell leukemia virus type $1 \mathrm{p} 40^{\mathrm{x}}$ protein and bovine papilloma virus encoded E2 protein. Neucleic Acids Res 1988; 16: 6547-65.

49 Arai N, Nomura D, Villaret D, DeWaal Malefijt R, Seiki M, Yoshida $\mathrm{M}$, et al. Complete nucleotide sequence of the chromosomal gene for human IL-4 and its expression. $\mathcal{F}$ chromosomal gene for huma

50 Miyatake S, Seiki M, Yoshida M, Arai K. T-cell activation signals and human $T$-cell leukemia virus type 1 -encoded p40 $0^{\mathrm{x}}$ protein activate the mouse granulocyte-macrophage colony-stimulating factor gene through a common DNA element. Mol Cell Biol 1988; 8: 5581-6.

$51 \mathrm{Kim}$ SJ, Kehrl JH, Burton J, Tendler CL, Jeang K-T, Daniel pour $\mathrm{D}$, et al. Transactivation of the transforming growth factor $\beta 1$ (TGF $\beta 1$ ) gene by human T lymphotropic virus type 1 Tax: a potential mechanism for the increased production of TGF- $\beta 1$ in adult $T$ cell leukemia. increased production of TGF- 


\section{NOTICES}

\section{Glaucoma Group}

DAVID COLE TRAVEL FELLOWSHIP

The David Cole Travel Fellowship, instituted by Merck Sharp \& Dohme in memory of Professor David Cole, will assist a visit to a hospital or research centre during the academic year starting 1 October 1995 . The award will be equivalent to $£ 2000$. The purpose of the award is to enable the successful applicant to gain experience and knowledge in pursuit of a specific project related to glaucoma.

\section{Wellcome General Overseas Travelling} Research Fellowships 1994-95

The purpose of these fellowships is to allow postdoctoral scientists and medical graduates to gain further research experience by working in leading laboratories in the UK or the Republic of Ireland. Applications are invited from such workers who wish to undertake a research project in any branch of the natural or clinical sciences, which has a bearing on human or veterinary medicine, with the exception of cancer.

Applicants may be from any country outside Europe, with the exception of New Zealand and the USA for whom special schemes are available. Awards will be made on the basis of the research proposal. The research proposed should be relevant to the research interests of the candidate in his/her own country. Awards are made for one year in the first instance, although requests for an extension may be considered. Fellowships provide a stipend within the range from $£ 13941$ to $£ 27869$ per annum, depending on age and experience. They also include the cost of research, attendance at scientific meetings, and return travel.

Candidates must be nominated by a sponsor in the UK or the Republic of Ireland, through whom all initial inquiries should be made. A preliminary proposal should include a one or two page outline of the research proposed, the curriculum vitae of the candidate, and a letter indicating that he/she has a position to return to at the end of the fellowship. There are no special deadlines for this scheme and applications may be submitted at any time during the year.

Requests for application forms should be addressed to: Dr J M Wilkinson, The Wellcome Trust, 183 Euston Road, London NW1 2BE. Tel: 0171-611 8407.

Candidates from New Zealand and the USA should contact the Health Research Council of New Zealand, Auckland, NZ or the Burroughs Wellcome Fund, Morrisville, NC 27560, USA, respectively, for details of appropriate schemes.

\section{Vth International Symposium on Sjögren's Syndrome}

The Vth International Symposium on Sjögren's syndrome will be held on 15-17 June 1995, in Noordwijkerhout, the Netherlands. Further details from: Conference secretariat: A A Kruize, Department of Rheumatology F02.223, University Hospital Utrecht, p/o Box 85500, 3508 GA, Utrecht, the Netherlands. (Tel: +31 30 507357; Fax: +3130523741.)
International Society for Clinical Electrophysiology of Vision

The 33rd ISCEV symposium will be held in Athens, Greece, 16-20 June 1995. The congress is organised by the International Society for Clinical Electrophysiology of Vision. Further details: Secretariat, Erasmus Conference Centre, International Congress Organisers, 227 Kifissias Ave, 14561 Kifissia, Greece. (Tel: (01) 6125022/3, 8054004; Fax: (01) 6125021.)

4th European Symposium of Traditional Ophthalmology

The 4th European Symposium of Traditional Ophthalmology will be held in Milan, Italy on 25-26 June 1995. Further details: Dottore Marzio Vanzini, Via Berleta 22, 40132 Bologna, Italy. (Tel: 39513824 01; Fax: 39 516232000 .)

\section{San Diego Eye Bank}

The San Diego Eye Bank is holding its 15th annual current concepts in ophthalmology conference on 11-13 August 1995 at the San Diego Princess Resort. Further details: Britta A Sullaway, Public Relations, San Diego Eye Bank, 3702 Ruffin Road, Suite 100, San Diego, CA 92123, USA. (Tel: (619) 694-0444; Fax: (619) 6940581.)

\section{The 21st International Pupil Colloquium}

The 21st International Pupil Colloquium will be held from 29 August to 2 September 1995 at Schloss Haigerloch, Tübingen, Germany. For further details: Helmut Wilhelm, University Eye Hospital, Department of Pathophysiology of Vision and NeuroOphthalmology, D-72076 Tübingen, Germany. (Tel: +497071 294786; Fax: +497071 295038.)

\section{European Strabismological Association}

The 22nd meeting of the European Strabismological Association (ESA) will be held in St John's College, Cambridge, UK

\section{Correction}

Because of a printer's error the wrong figure appeared as Figure 2 in the paper by Ono et al that was published in the March issue of the journal (BFO 1995; 79: 270-6). The correct figure is given below.

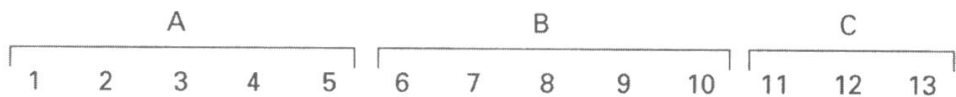

Figure 2 Quantitative PCR of HTLV-1 provirus DNA in the samples. An autoradiogram of the membrane hybridisation of the PCR products ( 30 cycles) with internal oligomer probe, $G 3$, is presented. The membrane was exposed to X-Omat AR film for 1 hour. (A) Fivefold dilution series of the positive control $\left(5^{0}\right.$ to $5^{-4}$ from lanes 1 to 5$)$; (B) samples from $H U$ patients (lanes 6 to 10 ); (C) samples from asymptomatic carriers (lanes 11 to 13). on 6-8 September 1995. Application papers, including abstract forms, can be obtained from: Mr J S Elston, MD, FRCS, Oxford Eye Hospital, Radcliffe Infirmary, Woodstock

\section{British and Eire Association of} Vitreo-Retinal Surgeons

The next meeting of the British and Eire Association of Vitreo-Retinal Surgeons (BEAVRS) will be held at Cameron House Loch Lomond, Glasgow on 5-6 October Members will be contacted with doctors wishing to attend should contact Dr H M Hammer or Dr T Barrie, Glasgow 7NB. (Tel: 0141-211 6767; Fax: 0141-

Joint European Research Meeting in Ophthalmology and Vision

the Joint European Research Meeting in Ophthalmology and Vision, its second meeting in Montpellier on 14-18 October 1995. Further details: JERMOV Secretariat - Chairman Agency, 34000 Montpellier, France. (Tel: +33 6715

\section{The Jules François Prize, 1997}

The Jules François Prize of the Belgian will be awarded for the sixth time in 1997 to tant contribution to ophthalmology. The aim of the prize is to encourage scientific research phere is no special theme. Fundamental as well as clinical research will be considered. The age limit is 40 years by riculum vitae, and three copies of published papers must be forwarded to the secretary of the Jules François Foundation. The closing date for applications is 31 December . Jules François Foundation, E Beernaertstraat 34, B-8400 Oostende, Belgium. 